\title{
A ética, a pesquisa e a publicação científica
}

\author{
Cristina Muccioli, Mauro Campos, Mauro Goldchmit, Paulo E.C. Dantas, Samir J. Bechara, Vital Paulino Costa
}

Se por um lado o mundo tecnológico moderno nos abre um caminho ao futuro, às reflexões relativas às novas práticas, aos desafios de novas descobertas, por outro lado parece nos distanciar de reflexões básicas e fundamentais como as discussões éticas.

O objetivo deste editorial é fazer uma reflexão sobre os aspectos éticos, legais e morais nas publicações cientificas.

No Brasil, desde outubro de 1996, foram estabelecidas as Diretrizes e Normas de Pesquisa envolvendo seres humanos, através da Resolução 196/96 do Conselho Nacional de Saúde e suas complementares, com o objetivo principal de garantir o respeito à pessoa. Garantia que se estende não só ao sujeito da pesquisa, ao pesquisador e equipe de pesquisa mas também à sociedade como um todo.

A avaliação ética de um projeto de pesquisa em saúde baseia-se na qualificação do projeto de pesquisa, na equipe de pesquisadores envolvidos, na avaliação do risco-benefício, no consentimento informado e também na prévia avaliação realizada por um comitê de ética.

Em todos os tipos de pesquisa clínica, o pesquisador principal é quem deve garantir o cumprimento dos processos éticos, das boas práticas clínicas, garantir o cuidado aos pacientes, ser responsável pelos dados da pesquisa e da equipe profissional envolvida como um todo. E como a publicação científica é o produto final de toda a pesquisa realizada, ele é o responsável pela autoria e co-autoria da publicação científica.

A autoria de publicações científicas é um assunto instigante e que tem gerado muitas discussões éticas nos últimos tempos. A questão "quem deve ser co-autor de um trabalho científico"? parece ainda não ter sido totalmente respondida.

Seria óbvio dizer que autor e co-autor de trabalhos científicos são aqueles que participaram ativamente em toda ou em parte da pesquisa, mas na prática nem sempre é o que acontece.

A omissão e a inclusão indevida de autores são práticas preocupantes e que geram situações extremamente desagradáveis e muitas vezes antiéticas.
Seria ético um simples relato de caso incluir mais do que cinco ou seis autores? É ético incluir o nome do Chefe do Departamento, do Setor, da Pós-graduação ou do sócio apenas pela posição que ocupam e não pela participação no trabalho?

De acordo com o Código de Ética Médica, Art. 137, é vedado ao médico - Publicar em seu nome trabalho científico do qual não tenha participado; atribuir-se autoria exclusiva de trabalho realizado por seus subordinados ou outros profissionais, mesmo quando executados sob sua orientação.

Para aqueles que acham que o simples fato de examinar um paciente vale a co-autoria, talvez essa questão gere uma revolta. Convém lembrar então que os autores e co-autores possuem responsabilidade ética, moral e legal pela publicação.

Na sua edição de 1988, o "International Committee of Medical Journal Editors", que tem por objetivo o estabelecimento de critérios comuns para a publicação de artigos científicos na área de saúde, publica os requerimentos uniformes para os manuscritos submetidos aos jornais biomédicos. De acordo com esse comitê, os critérios devem ser baseados somente em contribuições substanciais para: a) concepção, planejamento, análise ou interpretação dos dados; b) redação do artigo ou sua revisão intelectual crítica; c) responsabilidade pela aprovação final para publicação. Dessa forma, a participação apenas na obtenção de fundos ou na coleta de dados não justifica autoria. Outras contribuições devem ser reconhecidas separadamente, sob a forma de agradecimentos.

Também cabe aqui salientar os aspectos jurídicos dessa questão. Os autores e co-autores de trabalhos científicos também assumem a responsabilidade profissional, pública, ética e social da publicação de acordo com a Lei do Direito Autoral. Responsabilidades esta também compartilhada com os editores das revistas científicas e são considerados co-responsáveis pela publicação.

Portanto, cabe a nós editores, zelar pela ética das publicações da revista. 